\title{
Rescue transbrachial intra-aortic balloon insertion followed by percutaneous vascular access suture - case report
}

Ratunkowe założenie balonu do kontrapulsacji wewnątrzaortalnej z dostępu przez tętnicę ramienną z następczym zszyciem miejsca dostępu z użyciem urządzenia zamykającego - opis przypadku

\author{
Grzegorz Smolka', Ewa Peszek-Przybyła ${ }^{1}$, Wojciech Rychlik², Andrzej Ochała ${ }^{3}$ \\ 1Structural Heart Diseases Department, Upper Silesian Medical Centre, Katowice, Poland \\ ${ }^{2}$ Cardiac Intensive Care Unit, Upper Silesian Medical Centre, Katowice, Poland \\ $3^{\text {rdd }}$ Division of Cardiology, Medical University of Silesia, Upper Silesian Medical Centre, Katowice, Poland
}

Post Kardiol Interw 2012; 8, 1 (27): 57-60

DOI: 10.5114 pwki.2012.27927

\begin{abstract}
We describe a case of a 66-year-old man, with ischaemic cardiomyopathy, unstable angina and severe peripheral artery disease in whom after a successful percutaneous coronary intervention (PCI) of the circumflex branch with drug-eluting stent implantation, increasing vasoconstriction of the distal segment on guidewire occurred, resulting in vessel and systemic flow impairment, followed by cardiogenic shock. After about $1 \mathrm{~h}$ of resuscitation, due to haemodynamic instability, intra-aortic ballon pump (IABP) insertion via the transbrachial route was mandatory. Several minutes after IABP insertion, haemodynamic stabilization was obtained. Two $h$ after admission to the Cardiac Intensive Care Unit (CICU) the patient regained consciousness. The IABP was removed $16 \mathrm{~h}$ later with vascular access suture Angio-Seal applied. The transbrachial route may be considered as IABP access in patients with no other access route, but due to the small vessel diameter along with technical difficulties there is always a risk of artery thrombosis or limb ischaemia.
\end{abstract}

Key words: cardiogenic shock, intra-aortic balloon pump counterpulsation, transluminal percutaneous coronary angioplasty, closure device, transbrachial access

\section{Streszczenie}

Opisano przypadek 66-letniego chorego z niedokrwiennym uszkodzeniem mięśnia sercowego, niestabilną dławicą piersiową i nasiloną miażdżycą tętnic obwodowych, u którego po skutecznym zabiegu angioplastyki wieńcowej z implantacją stentu uwalniającego lek do tętnicy okalającej doszło do spazmu dystalnego odcinka naczynia i wstrząsu kardiogennego. Po około godzinnej resuscytacji, ze względu na utrzymujące się zaburzenia hemodynamiczne, zadecydowano o konieczności założenia balonu do kontrapulsacji wewnątrzaortalnej (intra-aortic balloon pump - IABP) z dostępu przez tętnicę ramienną. W ciągu kilku minut po założeniu IABP uzyskano stabilizację hemodynamiczną. Pacjenta przyjęto na oddział intensywnej terapii kardiologicznej, gdzie po 2 godzinach odzyskał przytomność. Balon do kontrapulsacji usunięto po 16 godzinach i zamknięto miejsce dostępu naczyniowego z użyciem urządzenia zamykającego Angio-Seal. Założenie IABP z dostępu przez tętnicę ramienną można rozważyć u pacjentów, u których nie ma innego dostępu naczyniowego. Niemniej jednak ze względu na niewielką średnicę naczynia oraz możliwe trudności techniczne należy zawsze liczyć się z możliwością wystąpienia zakrzepicy lub niedokrwienia kończyny.

Słowa kluczowe: wstrząs kardiogenny, kontrapulsacja wewnątrzaortalna, przezskórna angioplastyka wieńcowa, urządzenia zamykające, dostęp naczyniowy przez tętnicę ramienną

\section{Introduction}

One of the methods used for increasing coronary flow and decreasing afterload is the insertion of an intra-aortic balloon pump (IABP). According to American College of Cardiology/American Heart Association ACC/AHA standards, this method is classified as an I B recommendation and according to European Society of Cardiology guidelines it is classified as an I C recommendation for the treatment of cardiogenic shock during myocardial infarction. The most common indication for IABP insertion in trials on IABP

Corresponding author/Adres do korespondencji:

Ewa Peszek-Przybyla PhD, Structural Heart Diseases Department, Upper Silesian Medical Centre, 45 Ziołowa St, 40-653 Katowice, Poland,

tel./fax: +48 3225272 12, e-mail: ewapeszek@wp.pl

Praca wpłynęta: 14.11.2011, przyjęta do druku: 30.01.2012. 
implementation was cardiogenic shock [1]. Normally, transfemoral access is a typical IABP insertion approach. Although in most cases this approach is feasible, in some patients severe aorto-iliac and femoral atherosclerosis is an important issue.

We present here a case of successful IABP application during resuscitation after complicated percutaneous coronary intervention $(\mathrm{PCl})$, in a patient with bilateral severe iliac atherosclerotic disease and unfavourable femoral access. As severe stenosis in the right subclavian artery was present with the pulse impalpable at radial and brachial locations, IABP was not provided in advance for the time of $\mathrm{PCl}$.

\section{Case report}

A 66-year-old male, with severe ischaemic cardiomyopathy, was urgently admitted to the Cardiology Department due to episodes of cardiovascular decompensation. The patient had a history of two myocardial infarctions, with significant left ventricle systolic function impairment (ejection fraction about 21\%) and vast regions of wall akinesis, which involved $2 / 3$ of the anterior wall of the left ventricle, apex and interventricular septum. Also, echocardiography revealed pulmonary hypertension with maximal calculated pulmonary pressure of $63 \mathrm{~mm} \mathrm{Hg}$.

Other risk factors included renal failure, severe chronic obstructive pulmonary disease, and disseminated atherosclerotic disease of arteries (occlusion of left common iliac artery and subtotal occlusion of right common iliac artery). On physical examination, the right radial artery pulse was impalpable. Relative cardiovascular compensation had been achieved by intensive pharmacological treatment and coronary angiography was performed after that.

Coronary angiography was performed via a left transradial approach. Coronary angiography findings were as

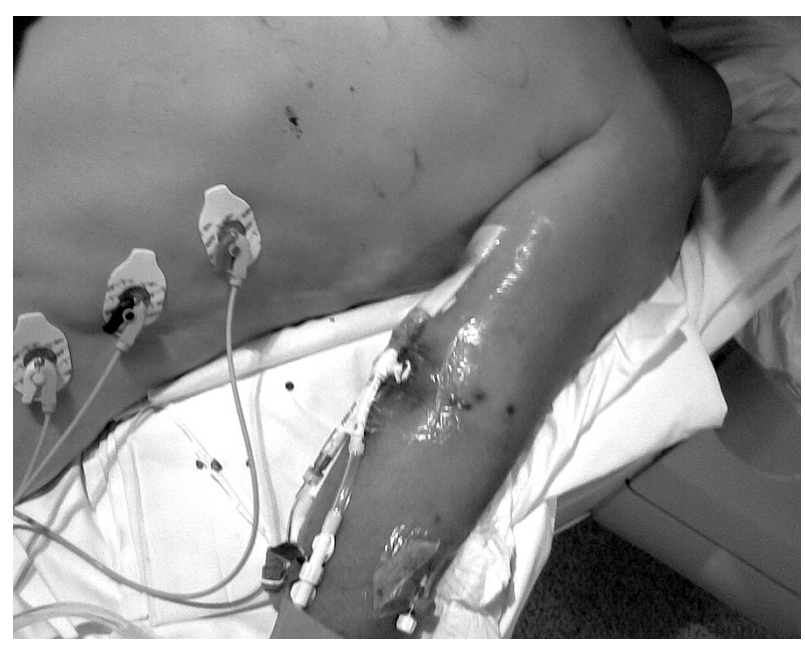

Fig. 1. "Sheathless" introduction of IABP via transbrachial access

Ryc. 1. „Bezkoszulkowe” założenie IABP z dostępu przez tętnicę ramienna follows: proximal occlusion of right coronary artery (distal vessel segment supplied by collateral circulation from left coronary artery), chronic occlusion of proximal segment of left anterior descending artery (with narrow distal segment supplied by collateral circulation) and critical (80\%) stenosis at distal left main and proximal circumflex branch, with dominating, very tortuous, obtuse margin branch and long critical stenosis in proximal segment of narrow vessel extension. In the cath lab the heart team (interventional cardiologist, cardiac surgeon) decided that due to the very high surgical risk (logistic EuroSCORE 35\%), and anatomical conditions unfavourable for complete revascularization, the patient was considered an ineligible candidate for cardiopulmonary bypass surgery. Therefore, we decided that during the same session, using the same transbrachial access, percutaneous treatment would be performed: an attempt of coronary angioplasty within left main and severely stenosed circumflex branch and consecutively cardioverter-defibrillator implantation was planned. After the application of a standard dose of unfractionated heparin and abciximab, predilatation of target lesion was performed, followed by implantation of drug-eluting stent Promus ( $3 \mathrm{~mm} \times 18 \mathrm{~mm}$ ), with good angiographic results. Increasing vasoconstriction of distal segment on guidewire occurred during the procedure, resulting in flow decrease in the vessel, with systemic arterial blood pressure decrease to $51 / 20 \mathrm{~mm} \mathrm{Hg}$, and haemodynamically inefficient rhythm $83 / \mathrm{min}$ appeared. Even though the guidewire was removed, cardiogenic shock followed by ventricular fibrillation and cardiac arrest occurred. Advanced life support procedures were implemented (defibrillation, external cardiac massage, intubation). Arterial blood gas analysis showed severe acidosis ( $\mathrm{pH}$ 6.9). Boluses of adrenaline and sodium bicarbonate, and infusion of maximal doses of two inotropic agents (adrenaline, dopamine) were administered. After $1 \mathrm{~h}$ of resuscitation, due to the patient's critical clinical state (haemodynamically inefficient sinus rhythm 100/min, consecutive VF episodes), and lack of femoral vascular access, we decided that IABP insertion was mandatory. The left brachial artery was punctured in the medial segment, with respect to IABP balloon length, so that after insertion the whole balloon length passed from the left subclavian artery to the descending aorta. A 7.5 Fr intra-aortic balloon pump was advanced "sheathless" (Figure 1), and proper positioning was confirmed under fluoroscopic guidance. Immediately after IABP insertion, haemodynamic stabilization of the patient was obtained with blood pressure 120/50 $\mathrm{mm} \mathrm{Hg}$.

The patient remained in a critical condition and was transferred to the Cardiac Intensive Care Unit (CICU), where he was ventilated, inotropic agents, abciximab and amiodarone were continuously administered and anti-cerebral oedema agents were given. Two hours after CICU admission the patient regained consciousness. Consecutive arterial blood gas analyses showed blood $\mathrm{pH}$ increase up to 7.2 
and then 7.4. Echocardiography performed at that time showed left ventricle contractility impairment as reported on admission. As left arm haematoma occurred after cannulation of the artery, the patient's brachial arterial flow was closely monitored (arterial flow assessed by pulse oximetry wave-forms and repeated, Doppler ultrasound examination), with no evidence of significant brachial artery compression or limb ischaemia.

Sixteen hours later, due to the patient's stable haemodynamic condition with IABP rate reduced to $1: 3$, we decided to remove the IABP balloon. As the required haemostasis was impossible to reach by standard means due to heparin and abciximab infusion and the atypical high arm puncture site, we decided to use a vascular closure device (Angio-Seal 8-Fr) (Figure 2). After seal application we achieved complete haemostasis; colour Doppler ultrasound showed no significant flow disturbances in the left brachial artery and no communication between the artery lumen and haematoma cavity. On day 3 , mechanical ventilation was ceased and the patient was extubated. The adrenaline dose was gradually reduced down to complete discontinuation; on the $11^{\text {th }}$ day, dopamine was discontinued as well. Maximal troponin T level during CICU stay was $13.59 \mathrm{ng} / \mathrm{ml}$ and maximal creatine kinase (CK-MB) activity was $336 \mathrm{U} / \mathrm{l}$. The clinical course was complicated by bilateral pneumonia (successfully treated with antibiotics); renal and liver function was deteriorating (serum creatinine max. $2.4 \mathrm{mg} / \mathrm{dl}$, glomerular filtration rate (GFR) $29 \mathrm{ml} / \mathrm{min} / 1.73 \mathrm{~m}^{2}$, SGPT (ALT) $73 \mathrm{U} / \mathrm{l}$, SGOT (AST) $46 \mathrm{U} / \mathrm{l}$ ).

The patient was transferred back to the Cardiology Department, where we observed improvement in liver and kidney function (SGOT $41 \mathrm{U} / \mathrm{l}$, SGPT $30 \mathrm{U} / \mathrm{l}$ ), creatinine decrease $\left(1.7 \mathrm{mg} / \mathrm{dl}\right.$, GRF $\left.43 \mathrm{ml} / \mathrm{min} / 1.73 \mathrm{~m}^{2}\right)$, and gradual resorption of left arm haematoma. Due to the significant clinical improvement and high periprocedural risk, control coronary angiography was abandoned. The patient was discharged in a stable haemodynamic condition, NYHA class III. During 11 months of follow-up, the patient did not require any hospitalisation; during the $11^{\text {th }}$ month the patient died suddenly (sudden cardiac death before planned CRT-D device implantation).

\section{Discussion}

In patients who are considered not suitable candidates for cardiac surgery, $\mathrm{PCl}$ is well-thought-out as an alternative treatment option. In most cases however, those procedures are usually at high risk of failure due to accompanying risk factors. The National Registry of Myocardial Infarction 2 [2] documented that in patients with cardiogenic shock, in whom percutaneous angioplasty is being performed, IABP usage did not significantly improve survival in comparison with patients without IABP support.

The presented case is "difficult", with refractory congestive heart failure, NYHA class IV and very low left ventricular ejection fraction. According to research results, in

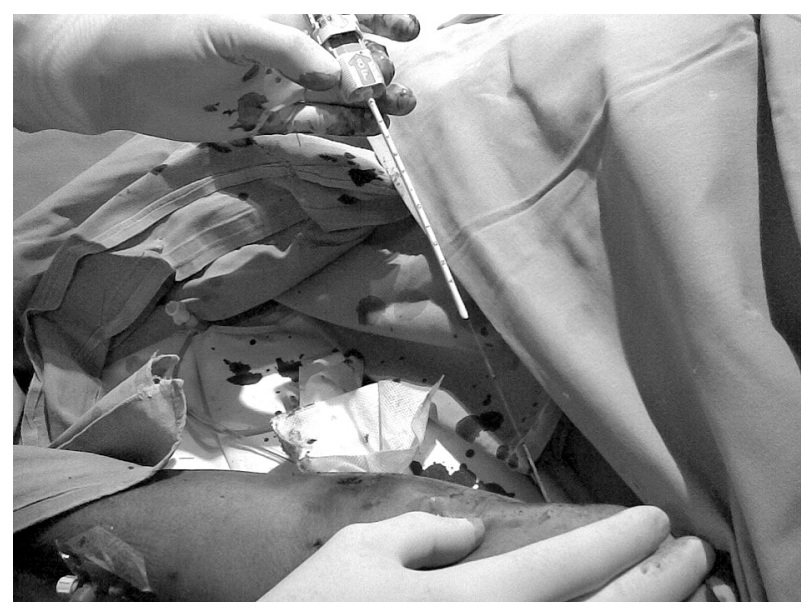

Fig. 2. Application of Angio-Seal at brachial artery IABP access site

Ryc. 2. Założenie Angio-Seal na tętnicę ramienna $w$ miejscu usunięcia IABP

patients with congestive heart failure, at this stage, the chance of surviving one year is about $50 \%[3,4]$. Moreover, an additional difficulty were the extremely unfavourable anatomical conditions (very tortuous and the only patient's vessel), which implied the necessity of fast and efficient procedure techniques and careful catheter manipulations. In the presented case, due to unsuitable iliac and right subclavian artery anatomy, the patient was not routinely protected by IABP insertion before the procedure. Brachial artery access for IABP insertion was used only due to the life-threatening condition of the patient.

Alternative routes for IABP insertion include the brachial artery, axillary artery and transaortic access. However, as axillary and transaortic access requires general anaesthesia and surgical procedures, the preferred method seems to be transbrachial access and probably the only one accessible during resuscitation. This access can still be technically challenging due to the relatively small brachial artery diameter, besides which the brachial artery also has to be punctured relatively high according to balloon length. It is also important to remember that the pressure line on the tip of the catheter is pointing away from the aortic valve, so it is not possible to synchronize the balloon timing on the arterial trace. The only possibility is to run the balloon on the ECG tracking only.

Recent experience, with recently introduced smaller catheter size (6-Fr and 7.5-Fr), allows ischaemic complications to be significantly reduced $[5,6]$. According to the Prospective Benchmark Registry [5], there is a significant difference between ischaemic limb complications: for 9.5Fr $2.9 \%$ and for 8 -Fr only $0.4 \%$. There are still limited data available concerning a 7.5-Fr catheter, but it seems that the complication rate should be similar to the rate related to an 8-Fr insertion. Onorati et at. [7, 8] analysed transbrachial IABP insertion in 10 consecutive patients with concomitant severe occlusive peripheral artery disease or 
abdominal aortic aneurysm. They showed that 7.5-Fr catheter usage in those patients is as efficient and as safe as transfemoral access. This method requires research on a broader group of patients though. Due to smaller vessel size in upper limbs and aortic arch anatomy, there is always a risk of hand ischaemia and cerebral embolism, especially in patients with severe peripheral vascular disease [9].

Even if the risk is as low as reported (according to Noël et al.), in right-handed patients the left brachial artery should be preferred to avoid dominating hand ischaemia, and also due to common difficulties arising related to brachio-cephalic trunk anatomy on the right side [10]. Pulse oximetry monitoring of parameters which may possibly inform about decreased peripheral perfusion in the IABP inserted arm is also a key issue.

In our patient's case, due to haemodynamic stabilization there was no need to continue IABP and we decided to remove the balloon pump on the second day to avoid further complications. An additionally important aspect was vascular suture (Angio-Seal) application to close the puncture site on the brachial artery after IABP removal. This suture is typically used on the femoral artery due to its larger diameter, but in this case efficient manual pressure on the punctured vessel was difficult to obtain, and to avoid further complications we decided to use it on the brachial artery as it was previously described by Lupattelli et al. [11]. Since the brachial artery anatomy allows for easy assess by Doppler ultrasound evaluation, we could check whether there were any symptoms of vessel stenosis at the seal application site (ultrasound examination immediately after vessel suture).

\section{Conclusions}

Intra-aortic balloon pump counterpulsation via transbrachial access is feasible but the femoral artery remains the customary access point. The transbrachial route may be considered as IABP access in patients with no other access route, but due to the small vessel diameter as well as technical difficulties, there is always a risk of artery thrombosis or limb ischaemia.

\section{References}

1. Lewis P, Mullany, DV, Townsend S, et al. Trends in intra-aortic balloon counterpulsation: comparison of a 669 record Australian dataset with the multinational Benchmark Counterpulsation Outcomes Registry. Anaesth Intensive Care 2007; 35: 13-19.

2. Barron HV, Every NR, Parsons LS, et al.; Investigators in the National Registry of Myocardial Infarction 2. The use of intra-aortic balloon counterpulsation in patients with cardiogenic shock complicating acute myocardial infarction: data from the National Registry of Myocardial Infarction 2. Am Heart 2001; 141: 933-939.

3. McMurray J, McDonagh T, Morrison CE, Dargie HJ. Trends in hospitalization for heart failure in Scotland 1980-1990. Eur Heart J 1993; 14: 1158-1162.

4. Cleland JG, Gemmell I, Khand A, Boddy A. Is the prognosis of heart failure improving? Eur J Heart Fail 1999; 1: 229-241.
5. Cohen M, Ferguson JJ 3rd, Freedman RJ Jr, et al. Comparison of outcomes after 8 vs. 9.5 French size intra-aortic balloon counterpulsation catheters based on 9,332 patients in the prospective Benchmark Registry. Catheter Cardiovasc Interv 2002; 56: 200-206.

6. Takahashi A, Taniguchi N. Supported percutaneous coronary intervention using a novel 6-Fr intra-aortic balloon pump catheter via the brachial artery in a nonagenarian patient with an abdominal aortic aneurysm. Catheter Cardiovasc Interv 2011; 77: 1045-1048.

7. Onorati F, Impiombato B, Ferraro A, et al. Transbrachial intraaortic balloon pumping in severe peripheral atherosclerosis. Ann Thorac Surg 2007; 84: 264-266.

8. Onorati F, Bilotta M, Pezzo F, et al. Transbrachial insertion of a 7.5FR intra-aortic balloon pump in a severely atherosclerotic patient. Crit Care Med 2006; 34: 2231-2233.

9. Werns $S$. Should the transbrachial route be used for intra-aortic balloon pumps? Almost never! Crit Care Med 2006; 34: 2259-2261.

10. Noël BM, Gleeton O, Barbeau GR. Transbrachial insertion of an intra-aortic balloon pump for complex coronary angioplasty. Catheter Cardiovasc Interv 2003; 60: 36-39.

11. Lupattelli T, Clerissi J, Clerici G, et al. The efficacy and safety of closure of brachial access using the AngioSeal closure device: experience with 161 interventions in diabetic patients with critical limb ischemia. J Vasc Surg 2008; 47: 782-788. 